\title{
Franchising our heritage: The UNESCO World Heritage brand
}

Bailey Ashton Adie ${ }^{a}$

${ }^{a}$ Research and Innovation, Southampton Solent University, Southampton, United Kingdom, bailey.adie@solent.ac.uk 
- Frames the UNESCO World Heritage structure as a franchise system.

- Analyzes UNESCO documents in comparison with franchise literature.

- Franchise system is useful to understand World Heritage site management. 
1 Franchising our Heritage: The UNESCO World Heritage Brand

2

3

4

5

6

7

8

9

10

11

12

The UNESCO World Heritage List has been continuously growing since the first sites were listed in 1978. It has frequently been highlighted as a marker of quality and authenticity, and UNESCO underscores that designation is important for tourist visitation. Given the vastness of the List, and its expected continued growth, it becomes relevant to understand the mechanism by which UNESCO and the States Parties work to promote the dissemination and use of the World Heritage brand. This paper proposes that the relationship between these entities is best expressed through a franchise model wherein UNESCO is the franchisor and the States Parties franchisees. Therefore, through an analysis of UNESCO World Heritage policy and practice documents combined with general franchising theory, this work seeks to emphasize the appropriateness of this business model in understanding the management practices of both UNESCO and the States Parties.

Keywords: UNESCO; World Heritage Brand; Franchise; World Heritage

\section{INTRODUCTION}

United Nations Educational, Scientific and Cultural Organization (UNESCO) World Heritage (WH) site status has often been lauded as a symbol of quality, with Ryan and Silvanto (2011, p. 306) calling it a "coveted brand and seal of approval." Therefore, it is unsurprising that there has been a consistent increase in submissions for inscription, with 1640 sites in 175 States Parties ${ }^{1}$ currently on the tentative list. This is in addition to the 1052 sites that have already been listed. Given the vastness of the WH List, and its expected continued growth, it becomes important to understand the mechanism by which the UNESCO WH Committee and the States Parties work to promote the dissemination and use of the WH brand. Therefore, this paper proposes that the relationship between these entities can be conceptualized as a franchise model wherein UNESCO is the franchisor and the States Parties franchisees. The concepts of franchising and UNESCO WH are rarely, if ever, discussed simultaneously. In fact, the idea that UNESCO works as a franchisor has only been mentioned twice. Probst (2007) presented the concept in relation to a cultural event which was part of a UNESCO initiative to fundraise for art-based strategies in Africa. This idea was in part derived from an opinion piece by Wolfgang Kemp (2005) wherein he notes that UNESCO licenses out its name. However, neither of these authors expanded on their ideas. Therefore, this work seeks to emphasize the appropriateness of this business model in understanding the management relationship that exists between UNESCO and the States Parties.

\section{THE FRANCHISE FORMAT}

\footnotetext{
${ }^{1}$ There are currently 193 States Parties that have ratified the WH convention. Of these, 189 are full members of the UN, with only Liechtenstein, Nauru, Somalia, and Tuvalu not being signatories. The other 4 States Parties are comprised of 2 permanent observers to the UN (the Holy See and Palestine) and 2 non-member states (the Cook Islands and Niue).
} 
A franchise can be identified as a business relationship, supported by a contract, wherein one organization, a franchisee, purchases, through initial fees and, later, royalties, the rights to the brand and business model of another organization, the franchisor (Combs et al., 2004; Blair \& Lafontaine, 2005; Badrinarayanan et al., 2016). These relationships are mutually beneficial for both parties and can be especially valuable when expansion is sought in international markets (Eroglu, 1992; Quinn, 1999). As stated, the basis of the franchise relationship is a contract that outlines the expectations for both actors as well as creating the power dynamic which will be in place during the duration of the arrangement (Rubin, 1978). This includes the give and take visible in terms of ownership and product quality control (Brickley \& Dark, 1987). Selection of appropriate franchisees, therefore, is of paramount importance. Brookes and Altinay (2011, p. 345) recommend "having a set of selection criteria and selection process in place" in order to assure that the appropriate franchisees are chosen. According to the empirical results found in Jambulingam and Nevin (1999, p. 389), these criteria should include "high [levels of] perceived innovativeness, and a high personal commitment to the business" in concert with more specific criteria derived from current successful franchise partnerships. In relation to their study of franchises in the tourism industry, Altinay et al. (2013, p.184) emphasize the importance of both franchisors and franchisees being well informed of "the feasibility of the franchise concept in their locations." These specific aspects will heighten the probability of a successful partnership for both parties.

Once the partners are selected and the contract is signed, there are certain requirements which both parties must fulfil. One of the most important of these, for the franchisor, is the expected inflow of cash. Franchisees make two separate payments throughout the contract period, an initial start-up fee and recurring royalties paid ad continuum (Shane, 1996; Blair \& Lafontaine, 2005). In terms of the initial franchise fee, Shane (1996, p. 77) highlighted that, based on his data, this "fee averages one-half of the total franchisor-specific investment." However, Lafontaine and Shaw (1999, p. 1044) indicate that the introductory payment amounts to only about eight per cent of a franchisee's total financial contribution. Therefore, royalties from usage of the franchisor's trademark or brand name are much more significant for the franchisor, often being a portion of total sales (Rubin, 1978). This system limits the franchisor's risk as "the proportional variability of franchisee sales is smaller than the variability of profits" (Caves \& Murphy, 1976, p. 579). Tikoo et al. (1999) advance this idea further by recommending that the rate be variable in order to not result in a stagnation of eventual sales. It is these two economic aspects which can often be most appealing to a franchisor.

For the franchisees, the brand, or trademark, of the franchisor is often considered the most important aspect of the partnership (Hunt, 1977; Nyadzayo et al., 2011). However, as Nyadzayo et al. (2011, p. 1108) note, "too often franchisees complacently expect the brand to sell itself based on the assumption that it is well-established." This can, in part, be remedied through the use of contractual requirements surrounding advertising fees, which are used to promote the brand at the national, regional, and local levels (Blair \& Lafontaine, 2005). It has also been noted that franchisors can assist in the construction of good brand citizenship from franchisees, specifically in terms of promotion, in order to enhance the overall brand equity (Nyadzayo et al., 2011). This can be achieved by "encourag[ing] existing franchisees to embrace the culture of self-driven positive brand-related attitudes" (Nyadzayo, 2015, p. 1893). Research by Badrinarayanan et al. (2016) indicates that brand resonance can be a 
particularly useful tool for franchisors in order to promote voluntary brand enrichment. Increased brand recognition is of particular importance when franchise companies choose to expand into international markets. For example, Lin et al. (2014) found that recognizable franchises were more likely to be used by foreign tourists who were visiting an area for the first time. However, in order for there to be a successful foreign expansion, the franchise system must promote the quality associated with the brand being purchased by the franchisees.

The franchise business type can be "characterised by a high degree of standardisation" (Quinn, 1999, p. 346) which functions as a benchmark of the franchise, a quality indicator. Rubin (1978) observed that quality must be maintained across all franchised units in order to preserve the brand's standing among its customers. Therefore, franchise contracts frequently require adherence to meticulously outlined quality standards, which are "especially important in businesses in which individual units cater to non-repeat customers" (Brickley \& Dark, 1987, p. 403). According to Brickley et al. (1991), sub-par quality levels at one franchised unit can have negative impacts on other franchisees in terms of a loss of customer volume as well as on the franchisor's trademark itself. Furthermore, in business format franchising it becomes critical to ensure uniform, high levels of service quality as fluctuations result in increased levels of customer dissatisfaction (Jeon et al., 2014). Thus, it can be seen that consumers expect a certain level of quality when dealing with a franchised brand, and a deviation from this quality level can significantly impact their perceptions of the brand.

As quality and brand maintenance are important franchisee responsibilities, it is unsurprising that problems could arise when they are not maintained, which can result in termination of the franchise contract. As Blair and Lafontaine (2005) observed, termination is not immediate, as most franchisors will spend a period of time attempting to convince the franchisee in breach of contract to alter their behavior. However, failure to comply often results in the commencement of termination procedures. It is important to note that while breach of contract allows for termination of the franchise agreement, it is up to the discretion of the franchisor, which is especially problematic as "termination could impose a substantial financial burden on the franchisee" (Makar, 1988, p. 760). Additionally, due to certain legal "good cause" requirements in several countries, notably in several states in the USA, contract termination can be particularly expensive for the franchisor in terms of both legal fees and, potentially, court-awarded damages to the franchisee if "good cause" is not found (Brickley et al., 1991). This can often be proven by "comparing the performance of the terminated franchisee with that of other, similarly situated franchisees" (Emerson, 1998, p. 596). Thus, termination is often a final resort of the franchisor as it is costly for all involved and must be well supported from a legal standpoint.

\section{THE WORLD HERITAGE FRANCHISE SYSTEM}

While the above discussion focuses exclusively on the franchise model from a purely business perspective, the following sections will address the application of these structures and processes to the existing WH operational framework. This is particularly important as several authors (Logan, 2012; Meskell, 2015; Meskell et al., 2015) note the increasing focus of the States Parties on the perceived potential economic benefits of listing. In fact, Logan (2012, p. 120), in his analysis of WH Committee sessions, stated that "World Heritage [is] seen by many as a brand and inscription little more than a branding exercise." Meskell (2015, 
p. 4) emphasizes the word "properties" in her discussion of $\mathrm{WH}$, referring to them as "commodities that mobilise national and international flows." Therefore, although the WH Convention arose from a desire to conserve and preserve natural and cultural heritage of global importance, the modern usage of listing by many States Parties has appeared to shift away from this focus towards one motivated by politics and economics.

In the following section, the franchise model, as outlined in the literature, has been applied to existing UNESCO WH policy and practice. This data was derived from an analysis of relevant documents which are readily available from UNESCO. More specifically, the following analysis will be broken into segments concentrating on the identified distinctive features of franchise relationships: selecting partners and the contract structure, contract fees and royalties, advertising and trademark regulations, quality control measures, and eventual contract termination.

\subsection{SIGNING THE CONTRACT}

The WH Convention was adopted on November 16, 1972. This international treaty laid the groundwork for the protective soft legislation surrounding WH sites and their management and established the WH Committee, which is the group that organizes the WH List. However, UNESCO is not actually responsible for the selection of the nominated sites. Instead, it is the responsibility of the respective States Parties to nominate those sites that they feel best represent the ideal of world heritage by illustrating each site's Outstanding Universal Value. This is defined as "cultural and/or natural significance which is so exceptional as to transcend national boundaries and to be of common importance for present and future generations of all humanity" (UNESCO, 2015, p. 11). In order to be considered for listing, sites must first go through a bidding process, wherein a State Party submits a nomination form demonstrating that they meet the WH criteria set by the UNESCO WH Centre. According to VanBlarcom and Kayahan (2011, p. 146), "the bidding process entails the preparation of a management plan, conducting supportive studies and consultation provided by third parties." These criteria and requirements are specific in nature in order to ensure that the selected sites best represent the idea of Outstanding Universal Value. This mirrors the process involved in the precontract interaction between a franchisor and franchisee, as can be seen in the framework in Figure 1.

\begin{tabular}{|c|c|c|c|c|c|c|c|c|c|}
\hline Franchisor & \multicolumn{9}{|c|}{ UNESCO } \\
\hline Franchisee & \multicolumn{3}{|c|}{ State Party } & \multicolumn{3}{|c|}{ State Party } & \multicolumn{3}{|c|}{ State Party } \\
\hline & & & $\neg$ & & & $\square$ & & & 7 \\
\hline Franchise Units & $\begin{array}{l}\text { WH } \\
\text { Site }\end{array}$ & $\begin{array}{l}\text { WH } \\
\text { Site }\end{array}$ & $\begin{array}{l}\text { WH } \\
\text { Site }\end{array}$ & $\begin{array}{l}\text { WH } \\
\text { Site }\end{array}$ & $\begin{array}{l}\text { WH } \\
\text { Site }\end{array}$ & $\begin{array}{l}\text { WH } \\
\text { Site }\end{array}$ & $\begin{array}{l}\text { WH } \\
\text { Site }\end{array}$ & $\begin{array}{l}\text { WH } \\
\text { Site }\end{array}$ & $\begin{array}{l}\text { WH } \\
\text { Site }\end{array}$ \\
\hline
\end{tabular}

Figure 1 UNESCO Franchise Framework

Furthermore, similarly to a franchise contract, the WH Convention (1972, p. 3) clearly outlines the balance of power by noting in Article 4 that "each State Party to this Convention recognizes that the duty of ensuring the identification, protection, conservation, presentation 
and transmission to future generations of the cultural and natural heritage." Additionally, according to Goodwin (2010),

after the nomination process is initiated...the treaty introduces a mechanism that emphasises the executive authority of the Committee over the World Heritage List. The Committee has control over: (1) initial admittance to the inventory; (2) officially declaring that an area of world heritage is danger; and (3) the deletion of a site from the World Heritage List (p. 288).

Therefore, the power dynamics are clearly defined, with the WH Committee holding administrative power over the States Parties while the States Parties are responsible for upholding the priorities of the convention. This can be seen as an obligation to maintain the trademark and quality levels expected of a site of Outstanding Universal Value, which will be discussed further in this work.

\subsection{CONTRACTUAL FEES AND ROYALTIES}

While UNESCO does not directly require fees in order to be a member or to sign the WH Convention, there are several payment systems in place. When initially joining UNESCO, Article 5.9 of the Basic Text (2012) states that

new Members shall be required to make a contribution for the financial period in which they become Members and provide their proportion of the total advances to the Working Capital Fund at rates to be determined by the General Conference. Such contributions shall be recorded as revenue in the year in which they are due.

While this fee is not directly related to being a signatory of the WH Convention, it is a compulsory payment for a State Party wishing to become a member of UNESCO, which can be understood as a parent company of the WH organization. Furthermore, there are compulsory contributions required by all signatories to the WH Convention which should be paid biannually and not exceed one per cent of the total amount they are expected to contribute to UNESCO as a whole (UNESCO, 1972). As the normal budget of UNESCO only requires fees that would match the estimated amount of money which the organization will be required to spend on activities within a given States Party (UNESCO, 2012), the WH compulsory contributions would be feasible independent of the economic level of a country.

Furthermore, although States Parties can opt out of this specific stipulation regarding compulsory fees, there is a strong recommendation that they should voluntary contribute an amount which is at least equivalent to what their compulsory contribution would have been. It should be noted that the Holy See, which has a quasi-state status in terms of international recognition, is a WH Convention signatory but not a member of UNESCO, and, thus, though they still pay voluntary contributions to the WH fund, they do not have required new member contributions. However, all other States Parties do have initial and continuing financial obligations to the franchisor, UNESCO.

In addition to these compulsory and voluntary contributions, there are also certain fees associated with the use of the official WH emblem when financial gain is anticipated. It is clearly stated in the Operational Guidelines (2015) that potential usage of the emblem needs to uphold the values of $\mathrm{WH}$ and not focus on the anticipated economic benefits, but 
this does not preclude its eventual use for commercial materials. This triggers a specific clause in the Operational Guidelines which states:

When commercial benefits are anticipated, the Secretariat should ensure that the World Heritage Fund receives a fair share of the revenues and conclude a contract or other agreement that documents the nature of the understandings that govern the project and the arrangements for provision of income to the Fund...National authorities are also called upon to ensure that their properties or the World Heritage Fund receive a fair share of the revenues and to document the nature of the understandings that govern the project and the distribution of any proceeds (2015, p.60).

These policies are consistent with the system of royalties found in general franchise systems, specifically as described in Rubin's (1978) work, wherein a royalty payment is often a percentage of total sales.

\subsection{ADVERTISING AND TRADEMARK}

One of the greatest benefits of being a member of a franchise network is the usage of an established brand, which Nyadzayo et al. (2011, p. 1107) refer to as the "focal asset franchisees are buying from franchisors." As sites are required to be of Outstanding Universal Value, as discussed in Section 3.1, this can be understood as one of the defining characteristics of the WH brand, emphasizing its distinction above national or local level heritage listings (World Heritage Centre, 2008). According to the WH Information Kit (World Heritage Centre, 2008), this eminence can be translated into external monetary support for the protection and management of the site as well as potential revenue from increased tourist visitation post-listing. The importance of the brand is further supported by the regulations for the plaques that are recommended by the most recent Operational Guidelines.

These plaques are designed to inform the public of the country concerned and foreign visitors that the property visited has a particular value which has been recognized by the international community. In other words, the property is exceptional, of interest not only to one nation, but also to the whole world (UNESCO, 2015, p. 58).

This again stresses the value of the WH brand to the international community as a signifier of global prestige.

The UNESCO WH brand's perceived distinction is also evident in the literature related to tourist visitation to WH sites. For example, Rakic and Chambers (2007, p. 146) refer to the WH List as "an accreditation scheme for heritage tourism attractions." Frey and Steiner (2011, p. 563), in a discussion of the advertising potential of listing, took this concept even further by noting that that "a site not in the UNESCO List is, by definition, not quite first, but rather second rate... The tourist industry understands well that not being on the List is a considerable disadvantage for its advertising." Ryan and Silvanto (2011, p. 306), as previously mentioned, refer to the WH brand as a "seal of approval" that operates as a guarantor of authenticity. King and Halpenny $(2014$, p. 1) take it one step further by stating that the "brand signals to the public a property so irreplaceable to humankind that its values must be sustained intact in perpetuity for the benefit of future generations." Therefore, the 
WH status can be understood as the established brand being purchased by the States Parties from UNESCO, which has international recognizability.

While standard forms of franchises generally require a certain percentage of the franchisee's profits in order to support advertising efforts, UNESCO uses a slightly diverse model. After a site is listed, States Parties are responsible for making sure the site is sufficiently marked as an official WH site, though "at the country's cost and with no assurance that visitors will recognize its meaning" (Di Giovine, 2009, p. 215). The UNESCO Operational Guidelines (2015) highlight the importance of placing the WH emblem in plain sight of visitors to the site, and, ideally, this would include a plaque, as previously mentioned, which has a standardized format. In addition to the utilization of the plaque as a prestige marker, they "have an additional function which is to inform the general public about the World Heritage Convention or at least about the World Heritage concept and the World Heritage List" (UNESCO, 2015, p. 58). States Parties are also encouraged "to make broad use of the Emblem such as on [the WH sites'] letterheads, brochures and staff uniforms" (UNESCO, 2015, p. 59), which assists in the enhancement of WH brand equity by providing greater visibility to WH visitors. Therefore, while States Parties are not expected to pay UNESCO for advertising as in a traditional franchise system, they are expected to pay for their own usage of the $\mathrm{WH}$ emblem, the most conspicuous marker of listing, and provide visibility for the overall $\mathrm{WH}$ brand.

\subsection{QUALITY CONTROL}

The control of the brand and advertising responsibilities discussed in section 3.3 are particularly important for the States Parties as tourism is "vulnerable to extreme variability" which is alleviated in part by recognizable brands that function as a standardized quality indicator (Clarke, 2000, p. 331). More specifically in relation to WH, "status has become a measure of quality assurance, a trademark and an 'authenticity stamp' for the heritage tourist and an arena for the presentation of prestigious national heritage, integral to the national building projects of States Parties" (Rakic \& Chambers, 2007, p. 146). WH serves as a substitute for missing knowledge by attesting that the WH site is the "real thing." The WH site "guarantee," as it is often regarded, spares the tourist or tour organizer the challenging task of judging and selecting potential sites on the basis of their intrinsic cultural merits and historic meanings. In sum, in the realm of heritage tourism, the WH brand is of critical importance because it testifies to historic attributes and developments that tourists, in many cases, would be unable to discern for themselves (Ryan and Silvanto, 2011).

In order to ensure the necessary quality level needed for brand association, all potential sites are required to satisfy three conditions, which are separate from the categorization of their Outstanding Universal Value. Integrity, the first of these three, is defined in the UNESCO Operational Guidelines (2015), as

a measure of wholeness and intactness of the natural and/or cultural heritage and its attributes. Examining the conditions of integrity, therefore requires assessing the extent to which the property:

a. Includes all elements necessary to express its Outstanding Universal Value;

b. Is of adequate size to ensure the complete representation of the features and processes which convey the property's significance; 
The second deals with the necessity for effective protection of the listed site. Adequate site management is the final condition for listing, specifically in the form of a comprehensive site management plan. Furthermore, sites that are nominated under Criteria I-VI are required to meet an additional requirement related to authenticity.

Properties may be understood to meet the conditions of authenticity if their cultural values (as recognized in the nomination criteria proposed) are truthfully and credibly

Only after national assessment and justification using these criteria can a site be nominated for World Heritage listing. As WH sites function as singularities and, in fact, are listed based on their "outstanding" uniqueness, these listing qualities provide a level of standardization in terms of experience and quality levels, similar to business format franchise systems.

In addition to the continued maintenance and protection measures, each site is subject to periodic reporting, which is undertaken for the following reasons:

a. To provide an assessment of the application of the World Heritage Convention by the State Party;

b. To provide an assessment as to whether the Outstanding Universal Value of the properties inscribed on the World Heritage List is being maintained over time;

c. To provide up-dated information about the World Heritage properties to record the changing circumstances and state of conservation of the properties;

d. To provide a mechanism for regional cooperation and exchange of information and experiences between States Parties concerning the implementation of the Convention and World Heritage conservation (UNESCO, 2015, p. 44).

As can be noted, this periodic reporting assists in the preservation, protection, and management of the WH sites while also allowing for the eventual possibility of UNESCO involvement when necessary. The reporting can also alert UNESCO to any possible danger faced by the site or damages already incurred which can result in placement either on the List of WH in Danger or eventual de-listing, which will be discussed in more depth in section 
3.5. Thus, periodic reporting functions as a quality management method in order to assure the continued high quality levels that are expected of the UNESCO WH franchise brand.

\subsection{BREACH OF CONTRACT \& TERMINATION}

Similarly to traditional business franchisees, States Parties are capable of being in breach of their contract, specifically in terms of financial obligations, trademark management, and maintenance of the expected quality levels as outlined in sections 3.2, 3.3, and 3.4 respectively. As mentioned in section 3.4, States Parties are required to undertake periodic reporting, though this only occurs once every six years. However, at any point reactive monitoring can occur, either in response to a report of deterioration of the site, which is thoroughly investigated, failure to undertake already noted alterations to protect or restore the site, or a State Party's notification of either "exceptional circumstances or work [that] is undertaken which may have an impact on the Outstanding Universal Value of the property or its state of conservation" (UNESCO, 2015, p. 37). However, the goal of this monitoring is to not only prevent deletion but also to remedy the situation if at all possible, similarly to the process that occurs in traditional franchise relationships when there has been a breach of contract.

Upon receiving notification of the potential problems at a $\mathrm{WH}$ site, the situation is assessed by the UNESCO Advisory Bodies: the International Council on Monuments and Sites (ICOMOS), the International Union for Conservation of Nature (IUCN), and the International Centre for the Study of the Preservation and Restoration of Cultural Property (ICCROM). As outlined in the UNESCO operational guidelines (2015, p. 39), these groups will verify the state of the site, and, dependent on its physical condition, there can either be no action, prescriptions for improvement, movement to the List of WH in Danger, or, potentially, complete deletion from the list. According to the Operational Guidelines (2015) current WH properties can only be inscribed on the List of WH in Danger if:

b) the property is threatened by serious and specific danger;

c) major operations are necessary for the conservation of the property;

d) assistance under the Convention has been requested for the property (p. 40).

Prior to being moved to the List of WH in Danger, UNESCO communicates with the State Party (or States Parties in the case of transboundary sites) responsible for the care and management of the site, and the two detail the required actions to remedy, as much as possible, whatever problem has been the catalyst for the movement of the site to the List. In order to support these actions, "a specific, significant portion of the World Heritage Fund" will be allotted to support the conservation efforts of these WH in Danger sites (UNESCO, 2015, p. 43).

Currently, there are 55 sites on the List of WH in Danger, of which 37 are cultural and 18 natural, and these are located within the boundaries of 34 States Parties, with 1 transboundary site. These sites will be reviewed every year in order to ascertain their current state of conservation as well as to plan for the future of each in regards to their WH status. Based on this information, the WH Committee, together with the relevant States Parties, can come to one of three decisions. They are as follows:

a) Additional measures are required to conserve the property; 
b) to delete the property from the List of World Heritage in Danger if the property is no longer under threat;

c) to consider the deletion of the property from both the List of World Heritage in Danger and the World Heritage List if the property has deteriorated to the extent that it has lost those characteristics which determined its inscription on the World Heritage List (UNESCO, 2015, p. 43).

Deletion is the ultimate decision that the WH Committee will make, and it is not done lightly. In fact, only two sites (the Arabian Oryx Sanctuary, Oman in 2007 and the Dresden Elbe Valley, Germany in 2009) have been deleted since the inception of the WH List.

Deletion should be seen as a breach of the UNESCO franchise contract, most notably as Article 4 of the WH Convention (1972, p. 3) commits each signatory State Party to "[ensure] the identification, protection, conservation, presentation and transmission to future generations of the cultural and natural heritage... situated on its territory." However, deletion from the WH List will only occur if either serious deterioration has occurred, destroying the site's Outstanding Universal Value, or "where the intrinsic qualities of a World Heritage site were already threatened at the time of its nomination by human action and where the necessary corrective measures as outlined by the State Party at the time, have not been taken within the time proposed" (UNESCO, 2015, p. 43). Nonetheless, prior to de-listing, the WH Committee will confer with the State Party responsible for the site in order to attempt to remedy the situation. This is in part because

deletion of a site...raises the spectre of immediate disadvantages, such as a loss of national esteem from public exposure of poor conduct, loss of visitor income to that site, and the weakening of political influence within national government structures...[T]he harmful consequences of deletion may also be more long term, impacting upon the future interests of the state party under the [WH Convention] (Goodwin, 2010, p. 308).

As with business franchise systems, the franchisor, UNESCO, is aware of the negative ramifications of "terminating" the franchisee's, the State Party's, contract and only commences with deletion if there is valid "good cause" and after significant intervention attempts.

\section{CONCLUSIONS}

This work has illustrated, through a presentation of the existing franchise literature and an analysis of UNESCO policy and practice, the relevance of the franchise model in relation to the implementation of the WH convention. As can be seen, signing the WH convention and nominating sites is similar to a franchise contract negotiation process. As a result of this process, the States Parties must ensure to abide by certain contractually binding regulations. For example, States Parties are required to pay compulsory contributions as well as royalty fees when a profit is expected from use of the WH emblem, which is similar to the income structure of a franchise system. Furthermore, States Parties are strongly encouraged to promote the WH brand while also maintaining the high quality level that this brand represents at each individual site, or franchise location. When these obligations are not fulfilled, the relevant sites can be deemed "in danger," which triggers assistance from UNESCO in order to remedy the problem(s). If the interventions are unsuccessful and/or ignored, then the 
relevant States Parties will be found in breach of contract which can trigger the deletion of the deteriorated site from the WH List.

However, this is not to say that there are not some complications when applying the franchise model to the WH system. Whereas traditional franchise systems are profit driven, UNESCO's stated purpose is to protect the world's heritage. However, as previously noted, often the rationale for the nominations is, in part, motivated by the prospect of economic gain through tourism receipts. While this does not correspond with their core goals, UNESCO does emphasize the importance of WH designation to tourism visitation as seen in the World Heritage Information Kit (2008), and this creates an important economic dynamic within the management relationship. Additionally, unlike a traditional franchise, there is no centralized advertising plan, with the onus of advertisement of the site lying with the individual States Parties. Furthermore, whereas there are clearly defined laws that dictate how franchise relationships function and protect both franchisor and franchisee, the WH convention operates as an international treaty, which operates as soft law. Nonetheless, the relationship between UNESCO and the States Parties shares the same distinct management characteristics that are found in traditional franchise systems.

By conceptualizing the relationship between UNESCO and the States Parties as that of franchisor and franchisee, it becomes easier to understand the existing macro-level management structures in place. More specifically, it provides an existing business framework by which to judge the levels of satisfaction of both parties involved in the WH management process. This can assist both the States Parties and the WH Committee should a dispute ever arise both in terms of understanding the source of the conflict as well as providing steps with which to solve it. Furthermore, this provides the groundwork for a new legal conceptualization of the WH convention, specifically in terms of the WH Committee's ability to ensure that States Parties uphold their responsibilities in regards to their listed sites. Future research should apply this model to individual case studies in order to assess the appropriateness of fit. Additionally, subsequent studies could analyze the legal ramifications of applying international franchise legislation to the signatories of the WH Convention. Furthermore, this framework can be applied to analyses of individual WH management studies in order to fully understand the shared responsibilities between UNESCO and the States Parties responsible for the site(s).

\section{Bibliography}

Altinay, L., Brookes, M., \& Aktas, G. (2013). Selecting franchise partners: Tourism franchisee approaches, processes and criteria. Tourism Management, 37, 176-185

Badrinarayanan, V., Suh, T., \& Kim, K.-M. (2016). Brand resonance in franchising relationships: A franchisee-based perspective. Journal of Business Research, 69, 3943-3950.

Blair, R.D. \& Lafontaine, F. (2005). The Economics of Franchising. Cambridge: Cambridge University Press.

Brickley, J.A. \& Dark, F.H. (1987). The choice of organizational form: The case of franchising. Journal of Financial Economics, 18, 401-420. 
Brickley, J.A., Dark, F.H., \& Weisbach, M.S. (1991). The economic effects of franchise termination laws. Journal of Law \& Economics, 34, 101-132.

Brookes, M. \& Altinay, L. (2011). Franchise partner selection: perspectives of franchisors and franchisees. Journal of Services Marketing, 25, 336-348.

Caves, R.E. \& Murphy, W.F., II (1976). Franchising: Firms, markets, and intangible assets. Southern Economic Journal, 42, 572-586.

Clarke, J. (2000). Tourism brands: An exploratory study of the brands box model. Journal of Vacation Marketing, 6, 329-345.

Combs, J.G., Michael, S.C., \& Castrogiovanni, G.J. (2004). Franchising: A review and avenues to greater theoretical diversity. Journal of Management, 30(6), 907-931.

Di Giovine, M.A. (2009). The Heritage-scape: UNESCO, World Heritage, and Tourism. Lanham, MD: Lexington Books.

Emerson, R.W. (1998). Franchise terminations: Legal rights and practical effects when franchisees claim the franchisor discriminates. American Business Law Journal, 35, 559-645.

Eroglu, S. (1992). The internationalization process of franchise systems: A conceptual model. International Marketing Review, 9(5), 19-30.

Frey, B.S. \& Steiner, L. (2011). World Heritage List: does it make sense? International Journal of Cultural Policy, 17, 555-573.

Goodwin, E.J. (2010). The consequences of deleting World Heritage Sites. King's Law Journal, 21, 283-309.

Hunt, S.D. (1977). Franchising: Promises, problems, prospects. Journal of Retailing, 53(3), 71-84.

Jambulingam, T. \& Nevin, J.R. (1999). Influence of franchisee selection criteria on outcomes desired by the franchisor. Journal of Business Venturing, 14, 363-395.

Jeon, H.-Y. J., Dant, R.P., \& Gleiberman, A.M. (2014). National versus local brands: Examining the influences of credence and experience services on customer perceptions of quality in a franchise context. European Journal of Marketing, 48, 1511-1535.

Kemp, W. (2005). Die UNESCO: Ein unverlangter Tätigkeitsbericht [UNESCO: An Unsolicited Progress Report]. Merkur, 680, 1140-1153.

Lafontaine, F. \& Shaw, K.L. (1999). The dynamics of franchise contracting: Evidence from panel data." Journal of Political Economy, 7, 1041-1080

Lin, Y.H., Lin, J.L., \& Ryan, C. (2014). Tourists' purchase intentions: impact of franchise brand awareness. The Service Industries Journal, 34, 811-827.

Logan, W. (2012). States, governance and the politics of culture: World Heritage in Asia. In P. Daly \& T. Winter (Eds.). Routledge Handbook of Heritage in Asia (pp. 113-128). Abingdon, UK: Routledge. 
Makar, S. (1988). In defense of franchisors: The law and economics of franchise quality assurance mechanisms. Villanova Law Review, 33, 721-766.

Meskell, L. (2015). Transacting UNESCO World Heritage: Gifts and exchanges on a global scale. Social Anthropology, 23 (1), 3-21.

Meskell, L, Liuzza, C., Bertacchini, E., \& Saccone, D. (2015). Multilateralism and UNESCO World Heritage: Decision-making, States Parties and political processes. International Journal of Heritage Studies, 21 (5), 423-440.

Nyadzayo, M.W., Matanda, M.J., \& Ewing, M.T. (2011). Brand relationships and brand equity in franchising. Industrial Marketing Management, 40, 1103-1115.

Nyadzayo, M.W., Matanda, M.J., \& Ewing, M.T. (2015). The impact of franchisor support, brand commitment, brand citizenship behaviour, and franchisee experience on franchiseeperceived brand image. Journal of Business Research, 68, 1886-1894

Probst, P. (2007). "An African Journey": On cultural heritage and the popularity of primitivism." RES: Anthropology and Aesthetics, 52, 153-160.

Quinn, B. (1999). Control and support in an international franchise network. International Marketing Review, 16, 345-362.

Rakic, T. \& Chambers, D. (2007). World Heritage: Exploring the tension between the national and the 'universal.' Journal of Heritage Tourism, 2, 145-155.

Rubin, P.H. (1978). The theory of the firm and the structure of the franchise contract. The Journal of Law \& Economics, 21(1), 223-233.

Ryan, J. \& Silvanto, S. (2011). A brand for all the nations: The development of the World Heritage brand in emerging markets. Marketing Intelligence \& Planning, 29, 305-318.

Shane, S.A. (1996). Why franchise companies expand overseas. Journal of Business Venturing, 11, 73-88.

UNESCO (1972). Convention Concerning the Protection of the World Cultural and Natural Heritage. Paris: UNESCO.

UNESCO (2012). Basic Texts. Paris: UNESCO.

UNESCO (2015). Operational Guidelines for the Implementation of the World Heritage Convention. Paris: UNESCO.

VanBlarcom, B.L. \& Kayahan, C. (2011). Assessing the economic impact of UNESCO World Heritage designation. Journal of Heritage Tourism, 6(2), 143-164.

World Heritage Centre (2008). World Heritage Information Kit. Paris: UNESCO World Heritage Centre. 


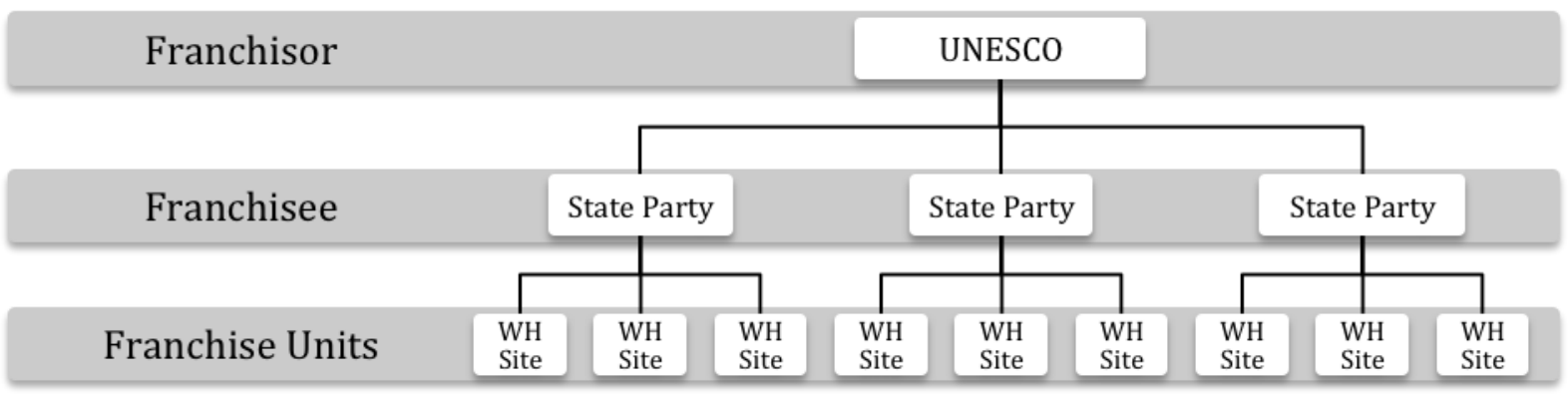

Figure 1 UNESCO Franchise Framework 
${ }^{*}$ Author Biography

Bailey Ashton Adie is a Postdoctoral Research Fellow at Southampton Solent University, Southampton, United Kingdom. She has a Ph.D. in Management and Development of Cultural Heritage from IMT Institute for Advanced Studies Lucca, Italy. Her research focuses on World Heritage tourism in an international comparative context, sustainable heritage tourism for community development, and tourism marketing and branding. 